\title{
Resistance of stud shear connectors in composite beams using profiled steel sheeting
}

\author{
Jorge Bonilla $^{\text {a, Luciano M. Bezerra }}{ }^{\mathrm{b}, *}$, Enrique Mirambell $^{\mathrm{c}}$ \\ ${ }^{a}$ Department of Mathematics, University of Ciego de Ávila, Cuba \\ ${ }^{\mathrm{b}}$ Department of Civil and Environmental Engineering, University of Brasília, Brazil \\ ${ }^{c}$ Department of Civil and Environmental Engineering, Polytechnic University of Catalunya, Spain
}

\section{ARTICLE INFO}

\section{Keywords:}

Composite beams

Profiled steel sheeting

Stud shear connectors

Push-out test

Longitudinal shear resistance

\begin{abstract}
A B S T R A C T
In composite beam design, headed stud shear connectors are commonly used to transfer longitudinal shear forces across the steel-concrete interface. This paper describes the structural performance of shear connection in composite beams with profiled steel sheeting. An accurate and efficient nonlinear Finite Element (FE) model was developed to study the behavior of headed stud shear connectors welded through the deck. The concrete slab considered in this article uses profiled steel sheeting with ribs perpendicular to the longitudinal axis of the steel beam. The material nonlinearities were included in the FE model. The concrete was modeled considering a damaged plasticity model available in ABAQUS software. The results obtained from FE analysis were verified against experimental results. A parametric study was conducted to observe the effects of changing of both the stud position inside the rib of profiled steel sheeting and the concrete strength on the resistance of the stud shear connector. The shear resistance of stud connectors obtained from the FE analysis and many experimental push-out tests whose results are available in the literature were used as a database to compare with design shear resistance calculated using AISC-LRFD and Eurocode 4. It is found that the shear resistance of stud connectors, obtained from the design rules specified in these codes, in some cases is greatly underestimated, and in other cases significantly overestimated.
\end{abstract}

\begin{tabular}{|ll|}
\hline Nomenclature \\
$A_{s c}$ & cross-sectional area of headed stud shear connector \\
$d$ & diameter of headed stud shear connector \\
$d_{c}$ & damage variable for concrete in uniaxial compression \\
$d_{t}$ & damage variable for concrete in uniaxial tension \\
$E_{c}$ & Initial Young's modulus of concrete \\
$E_{c m}$ & mean value of the secant modulus of concrete tabulated \\
& in the Eurocode 4 \\
$E_{s}$ & initial Young's modulus of headed stud shear connector \\
$f_{c}^{\prime}$ & specified minimum compressive strength of concrete \\
$f_{c k}$ & characteristic value of the cylinder compressive \\
& strength of concrete \\
$f_{c m}$ & mean value of concrete cylinder compressive strength \\
$f_{u}$ & specified ultimate tensile strength \\
$f_{y}$ & yield strength of steel
\end{tabular}

\footnotetext{
* Corresponding author.

Email address: lmbz@unb.br (L.M. Bezerra)
}

\begin{tabular}{|ll|}
\hline$F_{u}$ & specified ultimate tensile strength of the material of the \\
$h$ & stud \\
$h_{r}$ & height of headed stud shear connector \\
$n_{r}$ & nominal rib height \\
& number of shear connectors in one rib of the profiled \\
$w_{r}$ & average width of deck rib \\
$\sigma_{c}$ & compressive stress in the concrete \\
$\sigma_{t}$ & tensile stress in the concrete \\
$\varepsilon_{c}$ & compressive strain in the concrete \\
$\varepsilon_{c 1}$ & compressive strain in the concrete at the peak stress $f_{c m}$ \\
$\varepsilon_{c u 1}$ & nominal ultimate compressive strain in the concrete \\
$\varepsilon_{c}^{p l}$ & plastic strain in the concrete in compression \\
$\varepsilon_{t}^{p l}$ & plastic strain in the concrete in tension \\
$\varepsilon_{c}^{i n}$ & inelastic strain \\
$\mathrm{Q}_{\mathrm{sc}-\text { AISC-LRF }}$ nominal unfactored design strength calculated using \\
\\
$\mathrm{Q}_{\mathrm{sc}-\text { EC-4 }}$ & nominal unfactored design strength calculated using Eu- \\
& rocode 4
\end{tabular}




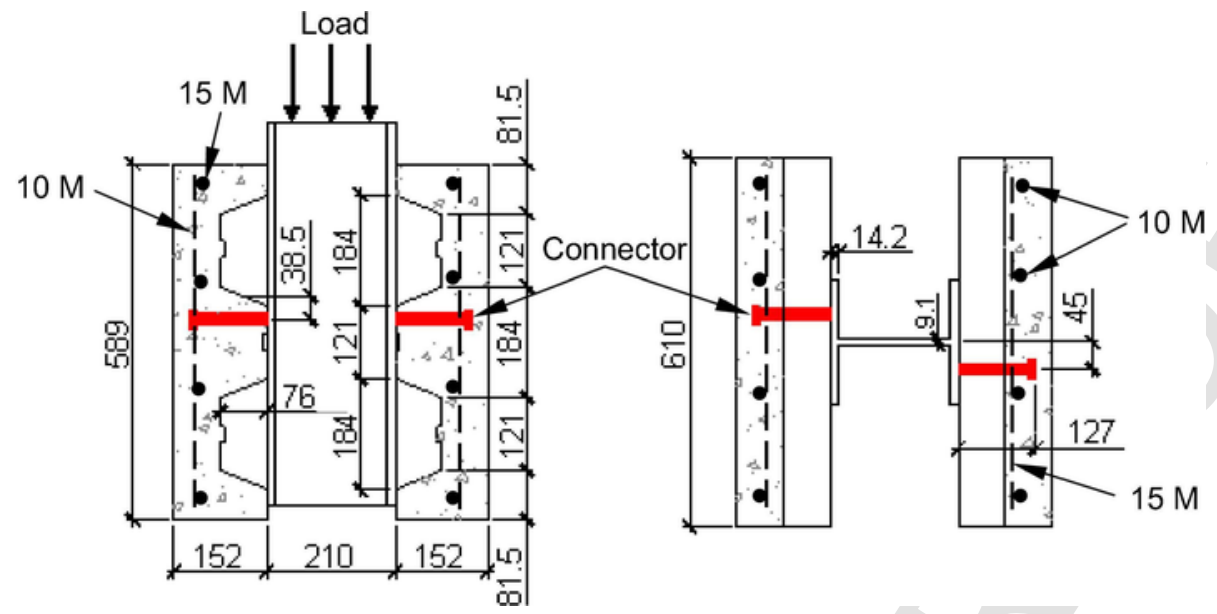

Fig. 1. Description of the Jayas and Hosain's [4] JDT-8 test specimen.

a)

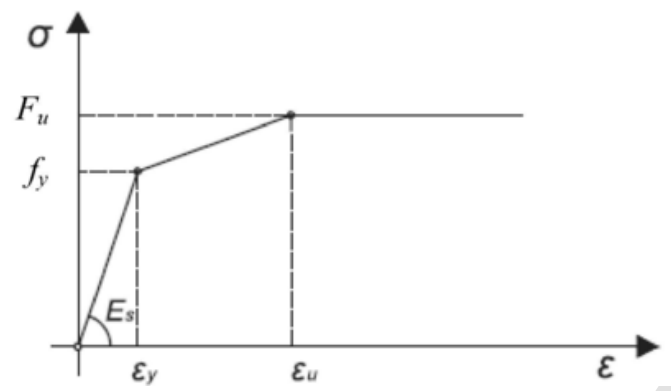

b)

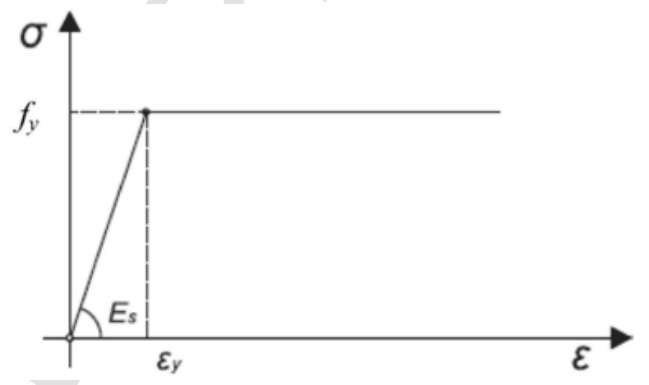

Fig. 2. Stress-strain relationship: (a) For studs, (b) For W steel beam, profiled steel sheeting and reinforcing bars.

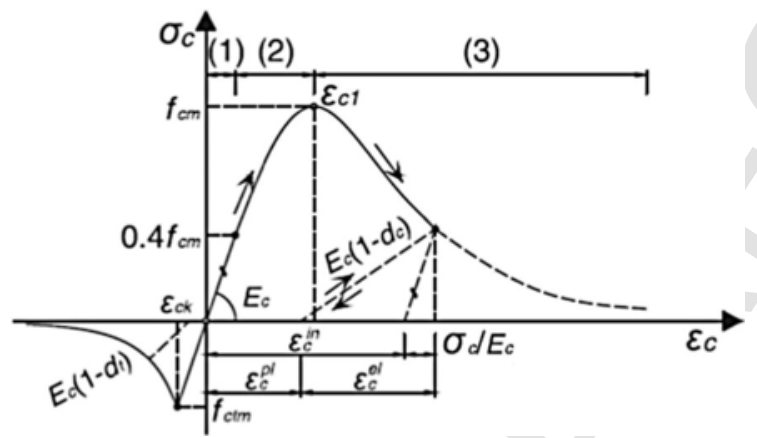

Fig. 3. Concrete stress-strain relationship for tension and compression [15].

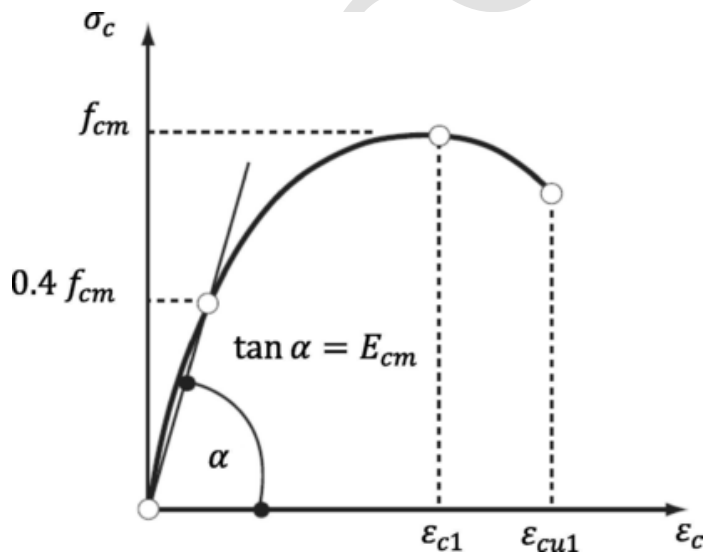

Fig. 4. Schematic representation of the stress-strain relation for structural analysis [33].

$\begin{array}{ll}\mathrm{Q}_{\text {sc - FE }} & \begin{array}{l}\text { capacity of shear connection per stud obtained from fi- } \\ \text { nite element analysis } \\ \text { capacity of shear connection per stud obtained from } \\ \text { push-out tests } \\ \mathrm{Q}_{\text {sc - test }}\end{array} \\ R_{g} & \begin{array}{l}\text { reduction factor associated with the number of studs in- } \\ \text { side the steel deck rib } \\ \text { reduction factor associated with the position of studs in } \\ \text { the steel deck rib }\end{array} \\ R_{p} & \end{array}$

\section{Introduction}

Composite construction using steel and concrete has been used since the early 1920s. It gained widespread use in bridges in the 1950s and in buildings in the 1960s $[1,2]$. In composite beams, steel and concrete are joined by mechanical connections. The most popular form being the welded headed shear stud. The stud is subjected to longitudinal shear force and its behavior is influenced by load conditions, shape of deck profile, spacing of shear connectors and other parameters. There are different types of steel-concrete composite beams. Some use solid slabs, others profiled steel sheeting with ribs in longitudinal or in perpendicular orientation with respect to the steel beam. Considering all the variations in steel-concrete beams, a lot of research is still needed to better understand the behavior of stud connectors. Generally, two approaches are used in exploring the behavior of such connectors: experimental and numerical. Experimental tests are expensive and time consuming but still the best to do to understand connections appropriately. However, numerical techniques are gaining importance since, as a general rule, they are faster and much cheaper than experimental tests in labs. This paper uses numerical techniques to study the behavior of stud connectors in steel-concrete composite beams with profile steel sheeting perpendicular to the steel beam. To perform such re- 
a)

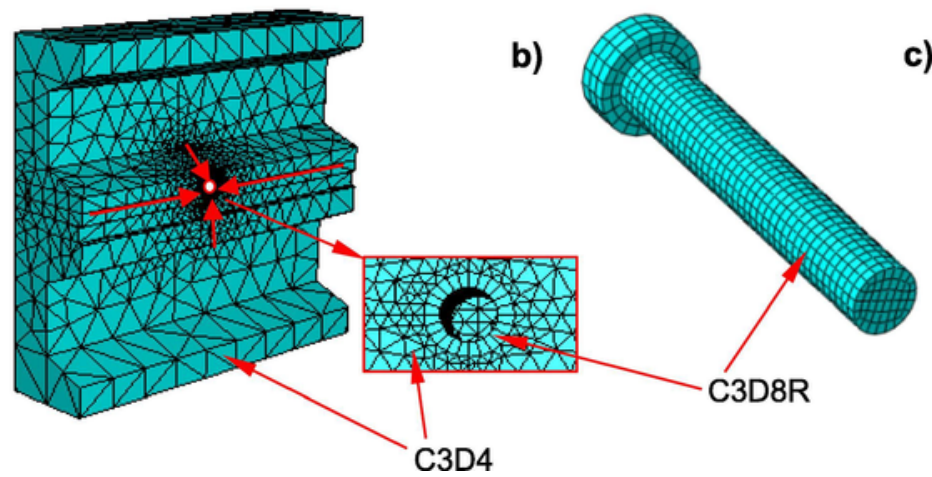

c)

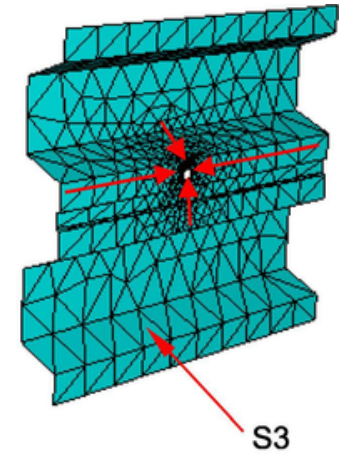

Fig. 5. Finite element mesh of the model: (a) Concrete slab, (b) Stud shear connector, (c) Profiled steel sheeting.

Table 1

Stud shear resistance behavior for different mesh densities.

\begin{tabular}{lllll}
\hline $\begin{array}{l}\text { Mesh } \\
\text { density }\end{array}$ & Part discretized & $\begin{array}{l}\text { Number of finite } \\
\text { elements }\end{array}$ & $\begin{array}{l}\mathrm{Q}_{\text {sc-FE }} \\
(\mathrm{kN})\end{array}$ & $\begin{array}{c}\mathrm{Q}_{\text {sc- }} \\
\text { test }\end{array} \mathrm{Q}_{\text {sc-FE }}$
\end{tabular}

* Qsc-test $=74.50 \mathrm{kN}[4]$.

search a large database of other numerical and experimental results was used based on research developed in recent years. In 1988, Robinson [3] performed 49 push-out tests on shear studs. He considered studs in weak position. Jayas and Hosain [4] achieved 18 push-out tests; 5 tests were in specimens with solid slabs, 5 and 8 testes with profile steel sheeting, respectively, with ribs parallel and perpendicular to the steel beam. Parameters such as longitudinal stud spacing and geometry of profile steel sheeting ribs were studied in [4]. In 1992, Sublett et al. [5] completed 36 push-out tests varying deck rib geometry, slab thickness and stud position, among other parameters. In 1994, Lyons et al. [6] executed 48 push-out tests with composite beams with solid slab; the effects of stud tensile strength and concrete properties on shear resistance were determined. 87 more tests used profile steel sheeting. Stud location and height and arrangement, profile steel sheeting height and thickness were considered. Based on push-out tests, Johnson and Yuan [7], in 1997, proposed equations to determine the resistance of studs under shear. Rambo-Roddenberry [2], in 2002, car-

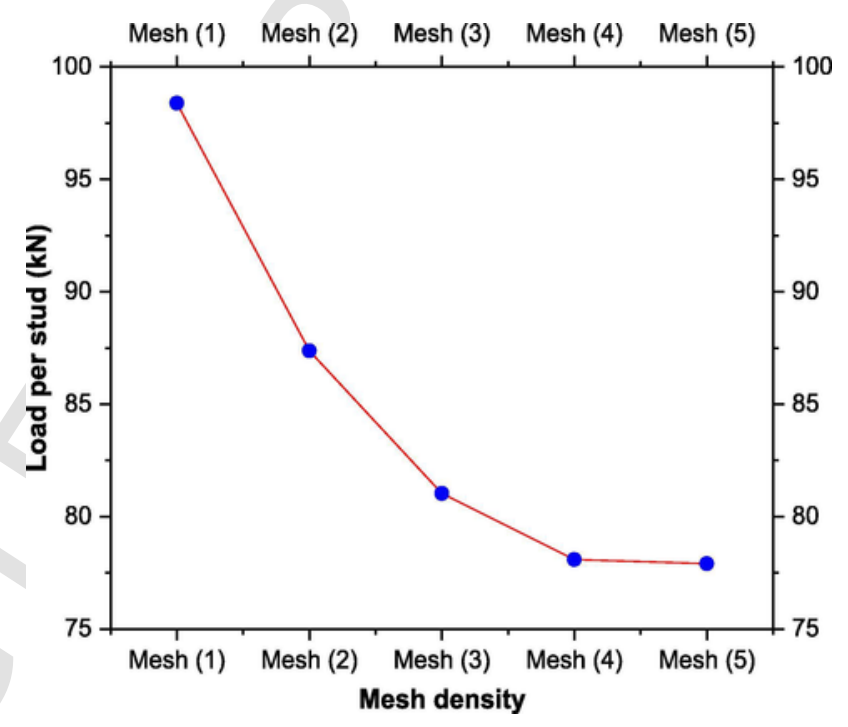

Fig. 6. Shear resistance behavior for different mesh densities.

ried out a large number of push-out tests, including 24 tests with solid slabs and 93 with profile steel sheeting. She obtained expressions to predict the stud shear resistance in profile steel sheeting with ribs perpendicular to the steel beam.

In the past 15 years different researchers have utilized FE to model composite structures with very good results [8-23]. Therefore, to provide further information $\mathrm{FE}$ technique can be used for analyzing steel-composite connection. The main objective of this paper is to develop an accurate and efficient nonlinear FE model of push-out tests, using ABAQUS [24] software, to investigate the behavior of headed stud shear connectors in composite beams with the profile steel sheeting ribs perpendicular to the steel beam. The results obtained from FE analyses have been verified against experimental tests whose results are available in the literature $[2-4,6]$. The material nonlinearities of concrete, headed stud, profile steel sheeting, reinforcement and steel beam were included in the FE model. Concrete was modeled considering damaged plasticity [25,26] available in ABAQUS [27]. A parametric study was conducted to investigate the effects of the stud position inside the profile steel sheeting rib and concrete strength on the resistance and behavior of shear connection. Efficient numerical models were developed and verified with experimental data. A large database of experimental results from worldwide different authors was used and employed to validate the numerical models. The results obtained from FE analyses and the experimental results available in the literature $[2-7,28]$ were compared with design shear resistance calculated using the American Specification (AISC-LRFD) [29] and Eurocode 4 (EC-4) [30]. It is found that in some cases the shear resistance of the stud con- 


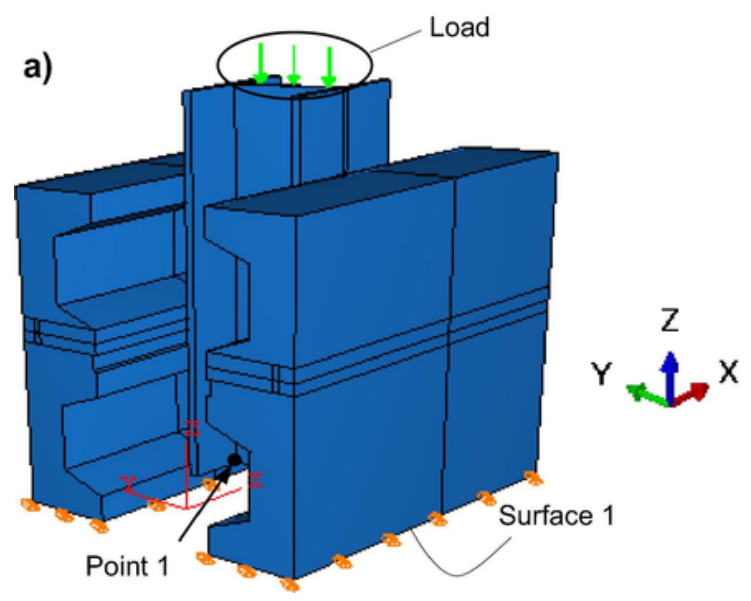

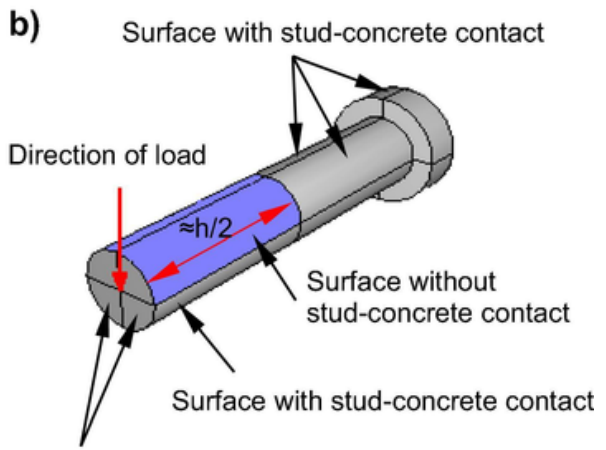

Surface with stud-W steel beam contact

Fig. 7. (a) Isometric view of the model in ABAQUS [24]. (b) Stud-concrete contact surfaces [40].

Table 2

Push-test specimens for the verification of FE model.

\begin{tabular}{|c|c|c|c|c|c|c|c|}
\hline Tested by & Specimen & $h_{r}(\mathrm{~mm})$ & $w_{r}(\mathrm{~mm})$ & $d \times h(\mathrm{~mm})$ & Stud position & $f_{c}^{\prime}(\mathrm{MPa})$ & $\mathrm{Q}_{\text {sc-test }}(\mathrm{kN})$ \\
\hline \multirow[t]{4}{*}{ Jayas and Hosain [4] } & JDT-5 & 38 & 61 & $16 \times 76$ & $2 \mathrm{MP}$ & 34.5 & 40.87 \\
\hline & JDT-6 & 38 & 92 & $16 \times 76$ & $2 \mathrm{MP}$ & 34.5 & 57.56 \\
\hline & JDT-7 & 76 & 153 & $19 \times 127$ & $2 \mathrm{SP}$ & 24.4 & 46.08 \\
\hline & JDT-8 & 76 & 153 & $19 \times 127$ & $1 \mathrm{SP}$ & 24.4 & 74.50 \\
\hline Robinson [3] & TVIII-A, B, C & 76 & 182 & $19 \times 116$ & $2 \mathrm{WP}$ & 22.1 & $47.75^{*}$ \\
\hline \multirow[t]{3}{*}{ Lyons et al. [6] } & $\mathrm{S} 1$ - D1, D2, D3 & 51 & 152 & $19 \times 89$ & $1 \mathrm{SP}$ & 31.4 & $97.46^{*}$ \\
\hline & S14 - D64, D65, D66 & 76 & 152 & $19 \times 127$ & StP & 18.4 & $59.80^{*}$ \\
\hline & S8 - D58, D59, D60 & 76 & 152 & $19 \times 127$ & $1 \mathrm{SP}$ & 23.2 & $82.62^{*}$ \\
\hline \multirow[t]{3}{*}{ Rambo-Roddenberry [2] } & D1 - D1, D2, D3 & 51 & 152 & $13 \times 100$ & $1 \mathrm{SP}$ & 30.5 & $38.98^{*}$ \\
\hline & D4 - D10, D11, D12 & 51 & 152 & $16 \times 100$ & $1 \mathrm{SP}$ & 20.1 & $61.71^{*}$ \\
\hline & D11 - D32, D33 & 51 & 152 & $19 \times 100$ & $2 \mathrm{SP}$ & 48.8 & $85.36^{*}$ \\
\hline
\end{tabular}

MP: Middle Position, SP: Strong Position, WP: Weak Position, StP: Staggered Position.

Note: In Fig. 11, Section 4, the stud positions inside the rib of profiled steel sheeting are shown.

* Average shear resistance of the stud connector in the series.

Table 3

Comparison of shear connection capacities obtained from tests and FE analysis.

\begin{tabular}{llll}
\hline Specimen & $\mathrm{Q}_{\text {sc-test }}(\mathrm{kN})$ & $\mathrm{Q}_{\text {sc-FE }}(\mathrm{kN})$ & $\mathrm{Q}_{\text {sc-test }} / \mathrm{Q}_{\text {sc-FE }}$ \\
\hline JDT-5 & 40.87 & 38.75 & 1.054 \\
JDT-6 & 57.56 & 53.68 & 1.072 \\
JDT-7 & 46.08 & 44.23 & 1.042 \\
JDT-8 & 74.50 & 77.91 & 0.956 \\
TVIII & 47.75 & 46.45 & 1.028 \\
S1 & 97.46 & 95.45 & 1.021 \\
S14 & 59.80 & 56.34 & 1.061 \\
S8 & 82.62 & 77.15 & 1.071 \\
D1 & 38.98 & 37.90 & 1.028 \\
D4 & 61.71 & 62.40 & 0.989 \\
D11 & 85.36 & 80.25 & 1.013 \\
& & & \\
Mean & & & 1.030 \\
COV & & & 0.034 \\
\hline
\end{tabular}

nectors is greatly underestimated, and in other cases significantly overestimated by AISC-LRFD and EC-4. Therefore an improvement on the current expressions for predicting the shear resistance of such stud shear connectors is required.

\section{Finite element model}

This study used the FE program ABAQUS [24] to investigate the behavior of shear connection in composite beams with profiled steel sheeting. In order to obtain accurate results from the FE analysis, all components in touch with the shear connection must be properly modeled. The main components affecting the behavior of shear connection in composite beams with profiled steel sheeting are: concrete slab, reinforced bars, stud shear connectors, profiled steel sheeting and steel beam. Both geometric and material nonlinearities are included in the FE analysis.

\subsection{Test specimen configuration}

This study is based on the virtual simulation of the push-out test. Jayas and Hosain's [4] JDT-8 test specimen was utilized for the calibration of the FE model. This specimen consisted of a structural W200 $\times 59$ beam section and two composite slabs with concrete compressive strength $\left(f_{c}^{\prime}\right)$ of $24.4 \mathrm{MPa}$ and Young's modulus $\left(E_{c}\right)$ of $23,200 \mathrm{MPa}$, placed on each side of the $\mathrm{W}$ beam section in contact with the flange. The connection between the composite slab and the flange is made by welded headed shear studs of $19 \times 127 \mathrm{~mm}(d \times h)$ with $F_{u}=450 \mathrm{MPa}$ and Young's modulus $\left(E_{s}\right)$ of $200,000 \mathrm{MPa}$. The composite slab was prepared using QL-Lock rib deck with a rib height $\left(h_{r}\right)$ of $76 \mathrm{~mm}$ and an average rib width $\left(w_{r}\right)$ of $152.5 \mathrm{~mm}$. The total height of the composite slab is $152 \mathrm{~mm}$ (see Fig. 1). 

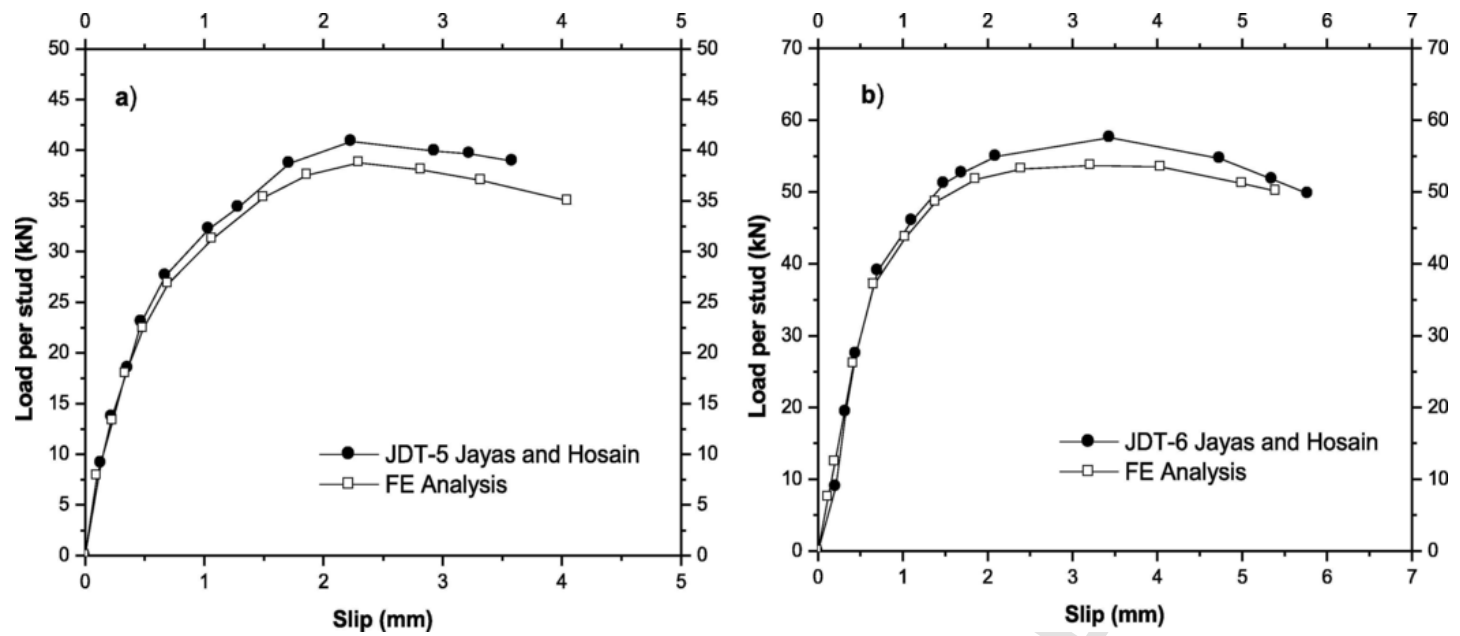

Fig. 8. Load per stud versus slip for push-out specimens JDT-5 and JDT-6.
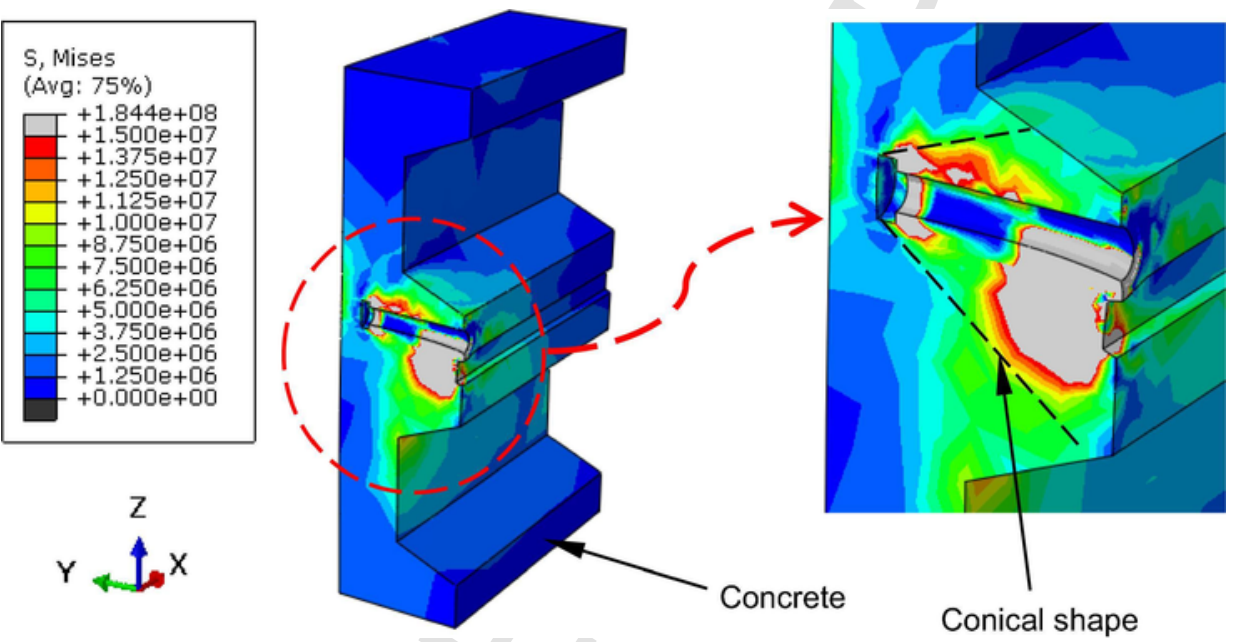

Fig. 9. Stress contours and deformed shapes of composite slab of push-out specimen JDT-8 at failure.
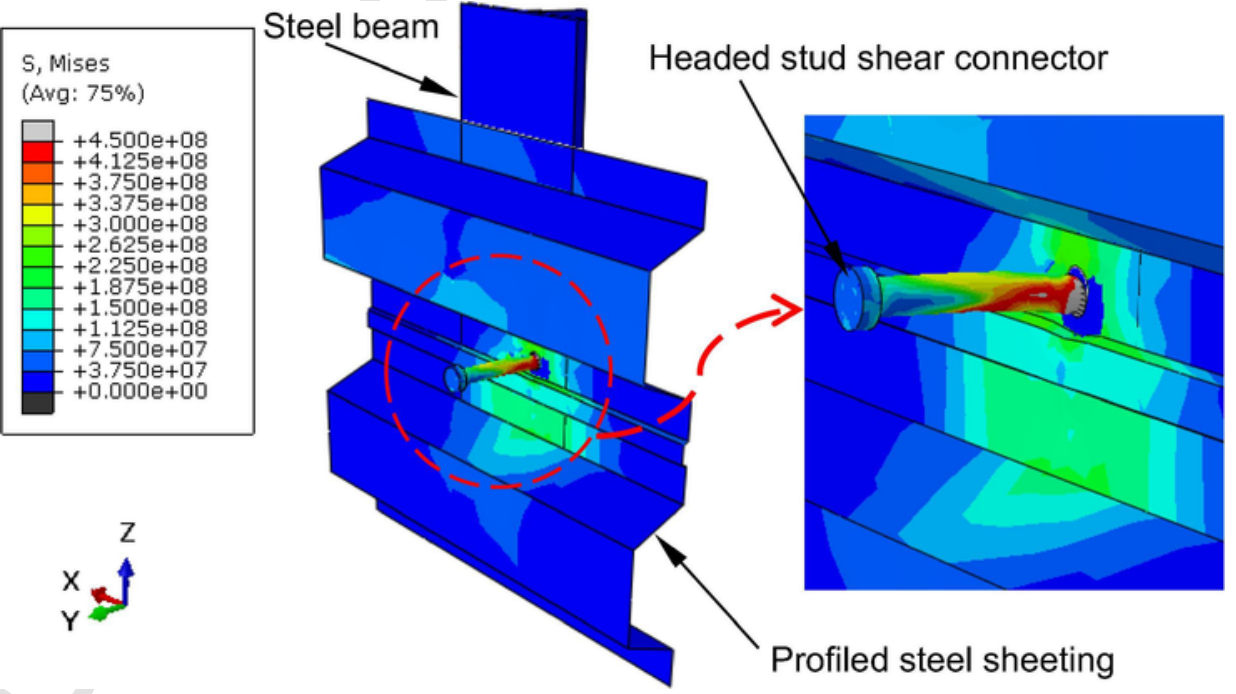

Fig. 10. Stress contours and deformed shape of the headed stud shear connector for the push-out specimen JDT-8 at failure. 


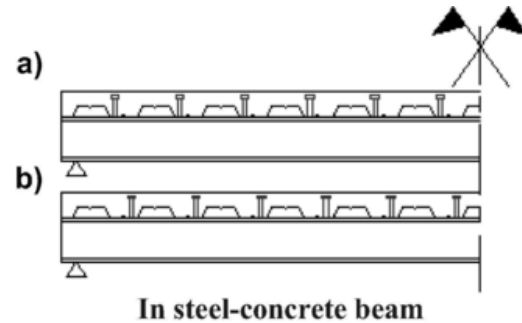

In steel-concrete beam

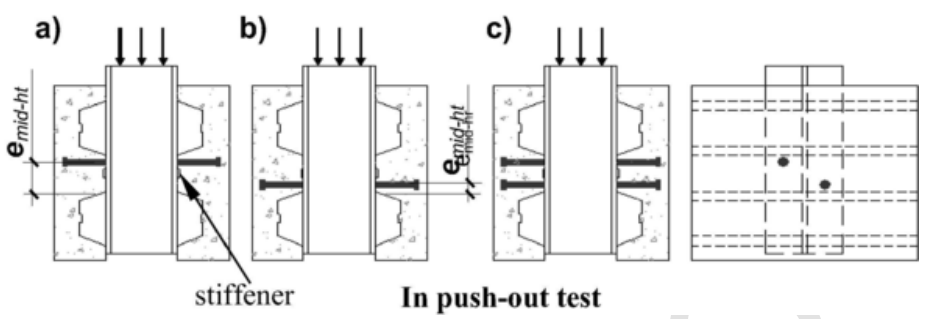

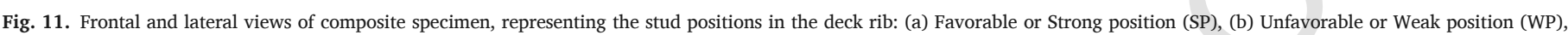
and (c) Staggered or Zigzag position (StP).

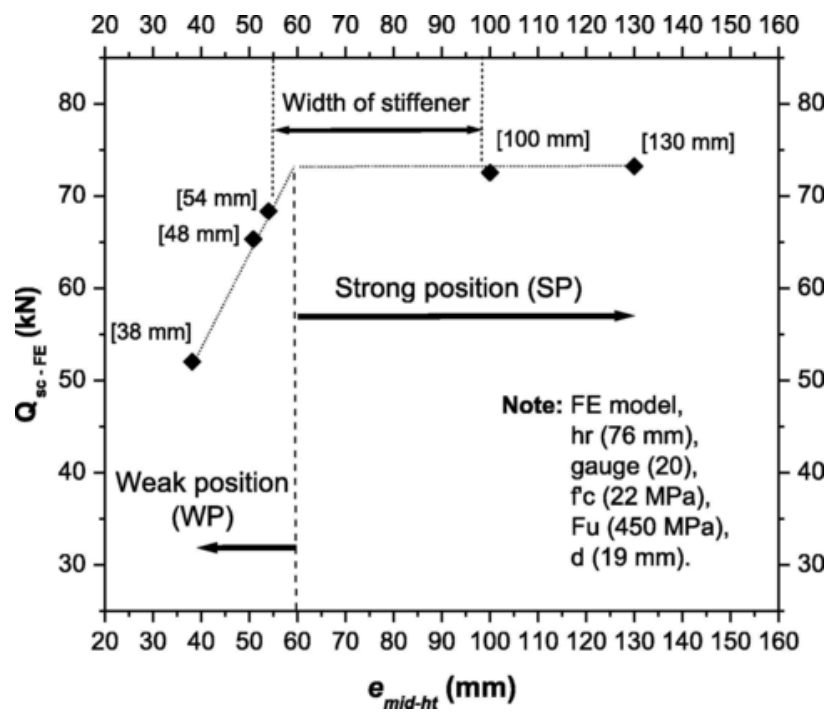

Fig. 12. Numerical stud shear resistance vs. stud position.

\subsection{Material modeling of steel}

Based on different research modeling of concrete-steel composite structures, a von Mises' criterion was adopted for the steel $[8-12,15,17]$. In this case the option (*PLASTIC) available in ABAQUS [24] was utilized. ABAQUS uses the classic rule of associated plastic flow and the isotropic yielding [24,27] to represent the behavior of steel material in the three-dimensional (3D) space of stresses. The shear stud material is of great importance in modeling the shear interaction between steel beam and concrete slab since the region around the stud is a region of severe and complex stresses [10]. The shear forces are

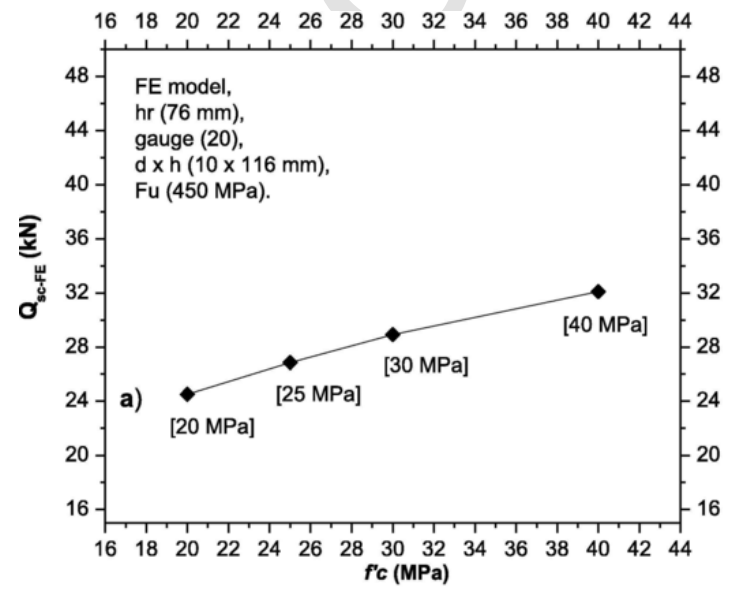

transferred across the steel beam-concrete slab interface by the mechanical action of shear connectors. Based on numerical studies by $\mathrm{Xu}$ et al. [15] to simulate the 3D behavior of the stud material accurately, ABAQUS [24,27] just needs the steel's uniaxial stress-strain curve which is represented, in this research, by the trilinear stress-strain curve shown in Fig. 2 (a). In this curve, the stud steel material behavior is initially elastic with Young's modulus $\left(E_{s}\right)$ followed by strain hardening and then yielding. In this analysis, $E_{s}, f_{y}, F_{u}$ and $\varepsilon_{u}$ were taken as $200,000 \mathrm{MPa}, 353 \mathrm{MPa}, 450 \mathrm{MPa}$ and $0.6 \%$, respectively. ABAQUS extends the steel uniaxial behavior to multiaxial stress state. Similarly, for W steel beam, profiled steel sheeting, and reinforcing bars, a uniaxial stress-strain curve is necessary, but in this case, for simplicity and based upon research conducted by Ellobody and Young [10], Lam and Ellobody [12], and Xu et al. [15], a bilinear stress-strain model is used as shown in Fig. 2 (b).

\subsection{Material modeling of concrete}

In concrete, cracking and crushing damage phenomena are important manifestations to be considered in appropriate FE simulations of concrete structures. In this work, concrete material was modeled considering the concrete damaged plasticity model available in ABAQUS $[24,27,31]$ based on the research by Lubliner et al. [25] and by Lee and Fenves [26]. This model provides a general capability for modeling concrete and other quasi-brittle materials. The damaged plasticity model is designed for applications in which concrete is subjected to monotonic, cyclic, and/or dynamic loading under low confining pressures and consists of the combination of nonassociated multi-hardening plasticity and scalar (isotropic) damaged elasticity to describe the irreversible damage that occurs during the fracturing process of concrete. The above mentioned model for concrete $[25,26]$ has been previously used by other authors, exhibiting good results $[8,9,11,15,17,18,21]$.

The concrete damaged plasticity model follows nonassociated plasticity flow rule, whereby the plastic potential function and the yield

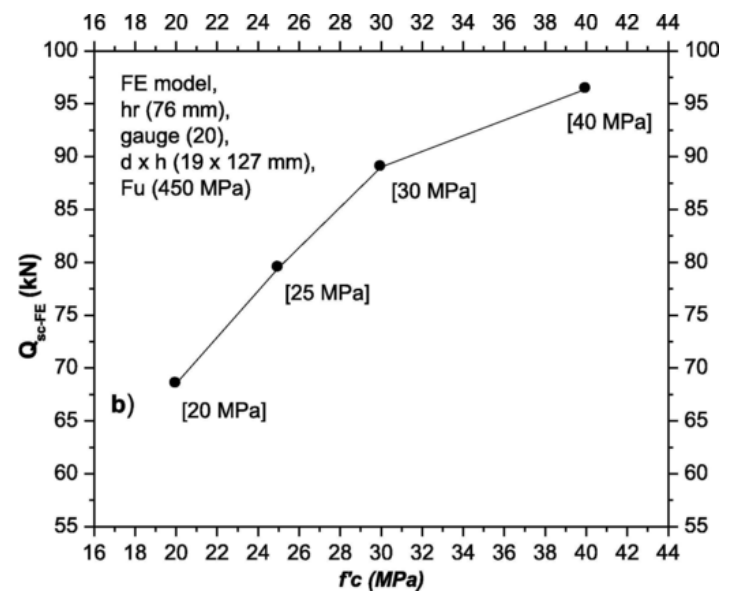

Fig. 13. Effect of concrete strength on shear resistance of stud: (a) $d=10 \mathrm{~mm}$ and (b) $d=19 \mathrm{~mm}$. 
Table 4

Effect of concrete strength on shear resistance of stud with the stud connectors in SP and StP positions.

\begin{tabular}{|c|c|c|c|c|c|c|c|}
\hline Source & Series & $h_{r}(\mathrm{~mm})$ & Number-Position & $d(\mathrm{~mm})$ & $f_{c}^{\prime}(\mathrm{MPa})$ & $\mathrm{Q}_{\mathrm{sc}-\mathrm{test} / \mathrm{FE}}(\mathrm{kN})$ & Increment (\%) \\
\hline Rambo-Roddenberry [2] & $\begin{array}{l}\text { D6 } \\
\text { D14 }\end{array}$ & 51 & 2-SP & 16 & $\begin{array}{l}20.10 \\
32.48\end{array}$ & $\begin{array}{l}60.49 \\
72.95\end{array}$ & Increase 20.59 \\
\hline Rambo-Roddenberry [2] & $\begin{array}{l}\text { D2 } \\
\text { D8 }\end{array}$ & 51 & 2-SP & 13 & $\begin{array}{l}30.54 \\
40.61\end{array}$ & $\begin{array}{l}36.87 \\
45.81\end{array}$ & Increase 24.25 \\
\hline $\begin{array}{l}\text { Lyons el al. [6] } \\
\text { Rambo-Roddenberry [2] }\end{array}$ & $\begin{array}{l}\text { S17 } \\
\text { D11 }\end{array}$ & 51 & 2-SP & 19 & $\begin{array}{l}24.27 \\
48.82\end{array}$ & $\begin{array}{l}66.72 \\
85.41\end{array}$ & Increase 28.01 \\
\hline Rambo-Roddenberry [2] & $\begin{array}{l}\text { D4 } \\
\text { D13 }\end{array}$ & 51 & 1-SP & 16 & $\begin{array}{l}20.10 \\
32.47\end{array}$ & $\begin{array}{l}61.71 \\
70.84\end{array}$ & Increase 14.80 \\
\hline $\begin{array}{l}\text { FE-a } \\
\text { FE-b }\end{array}$ & & 76 & 2-SP & 19 & $\begin{array}{l}20.00 \\
40.00\end{array}$ & $\begin{array}{l}60.30 \\
92.42\end{array}$ & Increase 53.27 \\
\hline $\begin{array}{l}\text { FE-c } \\
\text { FE-d }\end{array}$ & & 76 & 2-SP & 10 & $\begin{array}{l}20.00 \\
40.00\end{array}$ & $\begin{array}{l}22.82 \\
26.83\end{array}$ & Increase 17.57 \\
\hline $\begin{array}{l}\text { FE-e } \\
\text { Rambo-Roddenberry [2] }\end{array}$ & D20 & 76 & 1-SP & 10 & $\begin{array}{l}20.00 \\
36.12\end{array}$ & $\begin{array}{l}24.41 \\
31.42\end{array}$ & Increase 28.72 \\
\hline $\begin{array}{l}\text { FE-f } \\
\text { FE-g }\end{array}$ & & 76 & 2-StP & 19 & $\begin{array}{l}20.00 \\
40.00\end{array}$ & $\begin{array}{l}64.55 \\
86.50\end{array}$ & Increase 34.00 \\
\hline
\end{tabular}

From FE-a to FE-d: Numerical models with the same geometry of the specimen TII of Robinson [3].

FE-e: Numerical model with the same geometry of the specimen JDT-8 of Jayas and Hosain [4].

FE-f and FE-g: Numerical models with the same geometry of the specimen S14 of Lyons et al. [6].

Table 5

Effect of concrete strength on shear resistance of stud with the stud connectors in WP position.

\begin{tabular}{|c|c|c|c|c|c|c|c|}
\hline Source & Series & $h_{r}(\mathrm{~mm})$ & Number-Position & $d(\mathrm{~mm})$ & $f_{c}^{\prime}(\mathrm{MPa})$ & $\mathrm{Q}_{\mathrm{sc}-\text { test } / \mathrm{FE}}(\mathrm{kN})$ & Inc. or Dec. (\%) \\
\hline Rambo-Roddenberry [2] & $\begin{array}{l}\text { D5 } \\
\text { D15 }\end{array}$ & 51 & 1-WP & 16 & $\begin{array}{l}20.10 \\
32.48\end{array}$ & $\begin{array}{l}46.70 \\
42.04\end{array}$ & Decrease 9.9 \\
\hline Rambo-Roddenberry [2] & $\begin{array}{l}\text { D3 } \\
\text { D9 }\end{array}$ & 51 & 1-WP & 13 & $\begin{array}{l}30.54 \\
40.61\end{array}$ & $\begin{array}{l}29.75 \\
32.69\end{array}$ & Increase 9.88 \\
\hline $\begin{array}{l}\text { Lyons el al. [6] } \\
\text { Rambo-Roddenberry [2] }\end{array}$ & $\begin{array}{l}\text { S21 } \\
\text { D12 }\end{array}$ & 51 & 1-WP & 19 & $\begin{array}{l}18.75 \\
48.82\end{array}$ & $\begin{array}{l}54.26 \\
56.49\end{array}$ & Increase 4.11 \\
\hline $\begin{array}{l}\text { FE-h } \\
\text { FE-i }\end{array}$ & & 76 & 1-WP & 19 & $\begin{array}{l}20.00 \\
40.00\end{array}$ & $\begin{array}{l}63.70 \\
72.35\end{array}$ & Increase 13.57 \\
\hline
\end{tabular}

FE-h and FE-i: Numerical models with the same geometry of the specimen TVII of Robinson [3].

surface do not coincide with each other. For the flow potential ABAQUS [27] uses the Drucker-Prager hyperbolic function. Concrete can show significant volume change, commonly referred to as dilation, when subjected to severe inelastic stress states. The dilation can be represented by appropriate plastic potential function. On the other hand, the yield surface can be defined by the hardening rule. In this study, the dilation angle was taken as $13^{\circ}$ [32]. For all other plasticity parameters the default values suggested by ABAQUS $[24,27,31]$ were assumed.

In this study, the uniaxial stress-strain curve of concrete is shown in Fig. 3. Based on the numerical studies by $\mathrm{Xu}$ et al. [15], three parts of the stress-strain curve have been identified for concrete in compression. Given the uniaxial stress-strain curve, ABAQUS [24,27] can establish the multiaxial stress state behavior of concrete. A commonly used uniaxial stress-strain curve for concrete is given by EC-2 [33] as shown in Fig. 3. Such a curve is very reliable and commonly employed for concrete simulation; therefore, it was also used in this research. The first part of this curve is the initially assumed elastic range to the proportional limit stress. The value of the proportional limit stress is taken as $0.4 f_{c m}$, as presented in EC-2 [33]. The second part of the curve, in Fig. 3, is the nonlinear, parabolic portion starting from the propor- tional limit stress $0.4 f_{c m}$ to the ultimate strength $f_{c m}$. This part of the curve can be determined from expression (1), given by EC-2 [33].

$\frac{\sigma_{c}}{f_{c m}}=\frac{\eta k-\eta^{2}}{1+(k-2) \eta}$

where $\eta=\varepsilon_{\mathrm{c}} / \varepsilon_{\mathrm{c} 1}, \varepsilon_{\mathrm{c} 1}=0.7 f_{c m}{ }^{0.31} \leq 2.8$ and $\mathrm{k}=1.05\left(E_{c} \times\left|\varepsilon_{\mathrm{c} 1}\right|\right) / f_{c m}$ are defined according to EC-2 [33]. Expression (1) is valid for $0<\left|\varepsilon_{c}\right|<$ $\left|\varepsilon_{c u 1}\right|$ where $\varepsilon_{c u 1}$ is the nominal ultimate strain (see Fig. 4). According to EC-2 [33], the nominal ultimate strain, $\varepsilon_{c u 1}$, for concrete characteristic compressive cylinder strength of 12 to $50 \mathrm{MPa}$ can be taken as 0.0035 .

The third part of the curve, in Fig. 3, is the descending part. After exceeding the compression strain $\varepsilon_{\mathrm{c} 1}$, localization of damage occurs in the softening region. The following function [34], given by expression (2), has been chosen.

$\sigma_{c}=\left(\frac{2+\gamma_{c} f_{c m} \varepsilon_{c}}{2 f_{c m}}+\gamma_{c} \varepsilon+\frac{\gamma_{c}}{2 \varepsilon_{c}} \cdot \varepsilon^{2}\right)^{-1}$

where the value of $\gamma_{c}$ was taken to be 1.7 as recommended by $[15,35]$. 
Table 6

Experimental and numerical studies for the comparison with design shear resistance using AISC-LRFD [29] and Eurocode 4 [30].

\begin{tabular}{|c|c|c|c|c|}
\hline$h_{r}$ & Source & Series & $\begin{array}{l}d \\
(\mathrm{~mm})\end{array}$ & $\begin{array}{l}\text { Stud } \\
\text { position }\end{array}$ \\
\hline $25 \mathrm{~mm}$ & $\begin{array}{l}\text { Diaz et al. } \\
{[28]}\end{array}$ & ST2, ST3, ST5, ST6 & 10,13 & MP, 2 MP \\
\hline \multirow[t]{3}{*}{$51 \mathrm{~mm}$} & $\begin{array}{l}\text { Rambo- } \\
\text { Roddenberry } \\
{[2]}\end{array}$ & $\begin{array}{l}\text { D1, D2, D3, D4, D5, D6, } \\
\text { D7, D8, D9, D10, D11, } \\
\text { D12, D13, D14, D15, D16, } \\
\text { D18, D26, D27, D28, D29 }\end{array}$ & $\begin{array}{l}10, \\
13, \\
16,19\end{array}$ & $\begin{array}{l}\text { SP, } 2 \text { SP, } \\
\text { WP }\end{array}$ \\
\hline & $\begin{array}{l}\text { Lyons et al. } \\
{[6]}\end{array}$ & $\begin{array}{l}\text { S1, S2, S3, S4, S10, S14, } \\
\text { S17, S19, S21, S27, S28, } \\
\text { S29 }\end{array}$ & 19 & $\begin{array}{l}\text { SP, } 2 \text { SP, } \\
\text { WP, StP }\end{array}$ \\
\hline & $\begin{array}{l}\text { Sublett et al. } \\
\text { [5] }\end{array}$ & S3, S4, S14 & 19 & SP, WP \\
\hline $60 \mathrm{~mm}$ & $\begin{array}{l}\text { Johnson and } \\
\text { Yuan [7] }\end{array}$ & G4FL, G6U & 19 & SP, WP \\
\hline \multirow[t]{6}{*}{$76 \mathrm{~mm}$} & $\begin{array}{l}\text { Rambo- } \\
\text { Roddenberry } \\
{[2]}\end{array}$ & D20, D22 & 10 & SP, WP \\
\hline & $\begin{array}{l}\text { Lyons et al. } \\
\text { [6] }\end{array}$ & S6, S7, S8, S13, S14, S15 & 19 & SP, StP \\
\hline & $\begin{array}{l}\text { Sublett et al. } \\
\text { [5] }\end{array}$ & S1, S2, S13, S15, S16 & 19 & SP, WP \\
\hline & $\begin{array}{l}\text { Jayas and } \\
\text { Hosain [4] }\end{array}$ & S56-7JDT-7, S57-8JDT-8 & 19 & SP, 2 SP \\
\hline & Robinson [3] & QI, QII, TI, TII, TVIII & 19 & $\begin{array}{l}\text { SP, } 2 \text { SP, } \\
2 \text { WP }\end{array}$ \\
\hline & FE analysis & 36 numerical models & 10,19 & $\begin{array}{l}\text { SP, } 2 \text { SP, } \\
\text { WP, } 2 \\
\text { WP, StP }\end{array}$ \\
\hline $80 \mathrm{~mm}$ & $\begin{array}{l}\text { Johnson and } \\
\text { Yuan [7] }\end{array}$ & G1F, G3FL, G5U & 19 & SP, WP \\
\hline
\end{tabular}

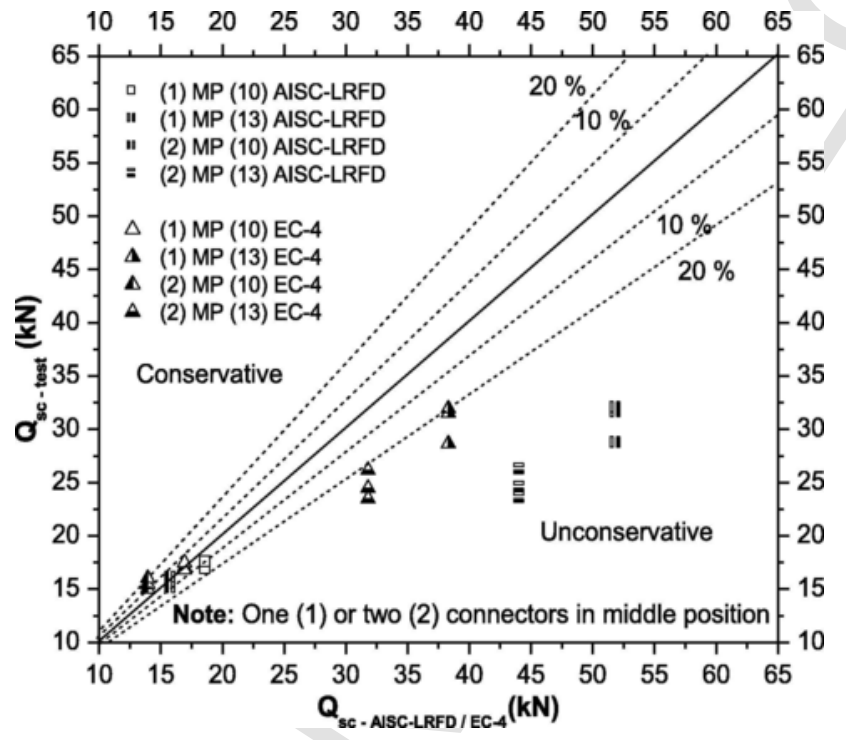

Fig. 14. Prediction of the stud connection resistance in profiled steel sheeting with $25 \mathrm{~mm}$ height based upon AISC-LRFD and Eurocode 4.

In Fig. 3, the degraded response of concrete is characterized by two independent uniaxial damage variables, $d_{c}$ and $d_{t}$. The damage variable is associated with concrete failure. When the damage variable is equal to zero, the concrete is not damaged; when the damage variable is equal to one, the concrete is completely damaged. For concrete in compression, the evolution of the compressive damage component $d_{c}$ is related to the corresponding plastic strain $\varepsilon_{c}^{p l}$ which is determined proportional to inelastic strain $\varepsilon_{c}^{i n}=\varepsilon_{c}-\sigma_{c} E_{c}^{-1}$, using a constant factor $b_{c}$ $\left(0<b_{c}<1\right)$ in expressions (3) and (4) as recommended by [35].

$$
d_{c}=1-\frac{\sigma_{c} E_{c}^{-1}}{\varepsilon_{c}^{p l}\left(\frac{1}{b_{c}}-1\right)+\sigma_{c} E_{c}^{-1}}
$$

where

$\varepsilon_{c}^{p l}=b_{c} \varepsilon_{c}^{i n}$

For concrete in tension, the tensile stress was assumed to increase linearly with respect to the strain until concrete cracking. After concrete cracking, tensile stress decreases nonlinearly to zero. In ABAQUS, concrete cracking initiates at a point when the plastic-damaged variable $d_{t}$ is greater than zero and the maximum principal plastic strain is positive. According to Lubliner et al. [25], concrete cracking direction is orthogonal to the maximum principal plastic strain at the damaged point. The value of the strain at zero stress can be taken as 10 times the strain at failure, as suggested in the ABAQUS manual [24,27]. The concrete cracking damage $d_{t}$ depends on $\varepsilon_{t}^{p l}$, as shown in expression (5). In this study, the constant factors $b_{c}$ and $b_{t}$ were both taken as $0.7[15,35]$.

$d_{t}=1-\frac{\sigma_{t} E_{c}^{-1}}{\varepsilon_{t}^{p l}\left(\frac{1}{b_{t}}-1\right)+\sigma_{t} E_{c}^{-1}}$

where

$\varepsilon_{t}^{p l}=b_{t} \varepsilon_{t}^{i n}$

\subsection{Finite element type and mesh}

Combinations of strut elements, shell elements and solid elements, which are available in the ABAQUS [24] element library, are used to model the push-out test specimen. Therefore, two-node elements (T3D2), three-node elements (S3) and eight-node elements (C3D8R) are used to model the reinforcement bars, the profiled steel sheeting and the stud shear connectors, respectively. In the modeling of the concrete slab around the stud, C3D8R elements are used and four-node elements (C3D4) are used elsewhere (see Fig. 5). The meshes in the concrete slab and in the profiled steel sheeting were employed with variable density, refining the mesh towards the slab-stud contact area. The mesh has a uniform size in the connectors. To avoid numerical imprecisions, the shape of the elements satisfies the limits and the aspect ratio for shell and solid elements as recommended by ABAQUS [24]. The mesh density was studied by Bonilla [36] throughout five configurations of meshes, and a summary of the results is presented in Table 1 . The relation between capacity of shear connection per stud from the FE modeling and tests, or $\mathrm{Q}_{\mathrm{sc}-\mathrm{FE}} / \mathrm{Q}_{\text {sc-test }}$, is reported in that table according to the number of finite elements used in the discretized parts. The $\mathrm{Q}_{\mathrm{sc}-\mathrm{FE}} / \mathrm{Q}_{\mathrm{sc}-\mathrm{test}}$ ratio closer to one means the mesh is better in simulating the test. Figure 6 shows graphically the FE results of "load per stud" vs "mesh density" (1) to (5). In that figure, convergence to the test value $(74.50 \mathrm{kN})$ in Mesh (4) and Mesh (5) can be observed, where the $\mathrm{Q}_{\mathrm{sc}-\mathrm{FE}} / \mathrm{Q}_{\text {sc-test }}$ ratios are, respectively, 0.954 and 0.956 . Mesh (5) was adopted in the research. 

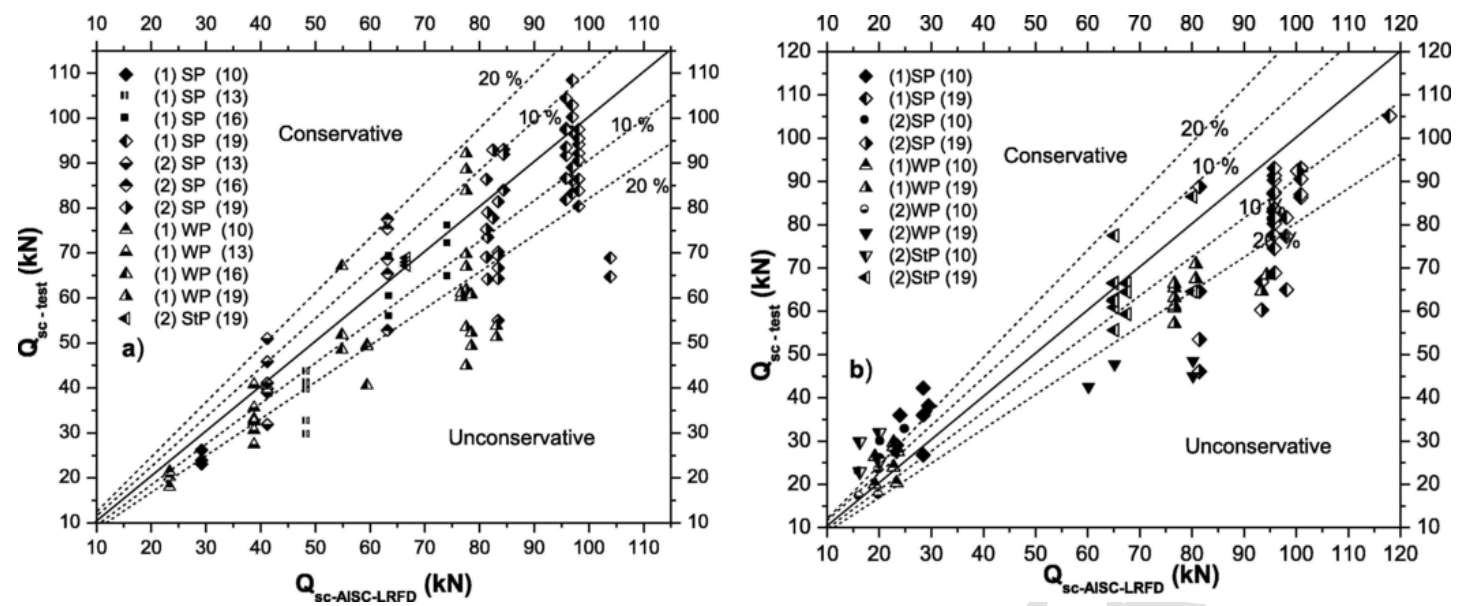

Fig. 15. Prediction of the shear resistance according to AISC-LRFD for profiled steel sheeting with different heights (hr): (a) $\mathrm{hr}=51 \mathrm{and} 60 \mathrm{~mm}$, and (b) hr $=76 \mathrm{and} 80 \mathrm{~mm}$.
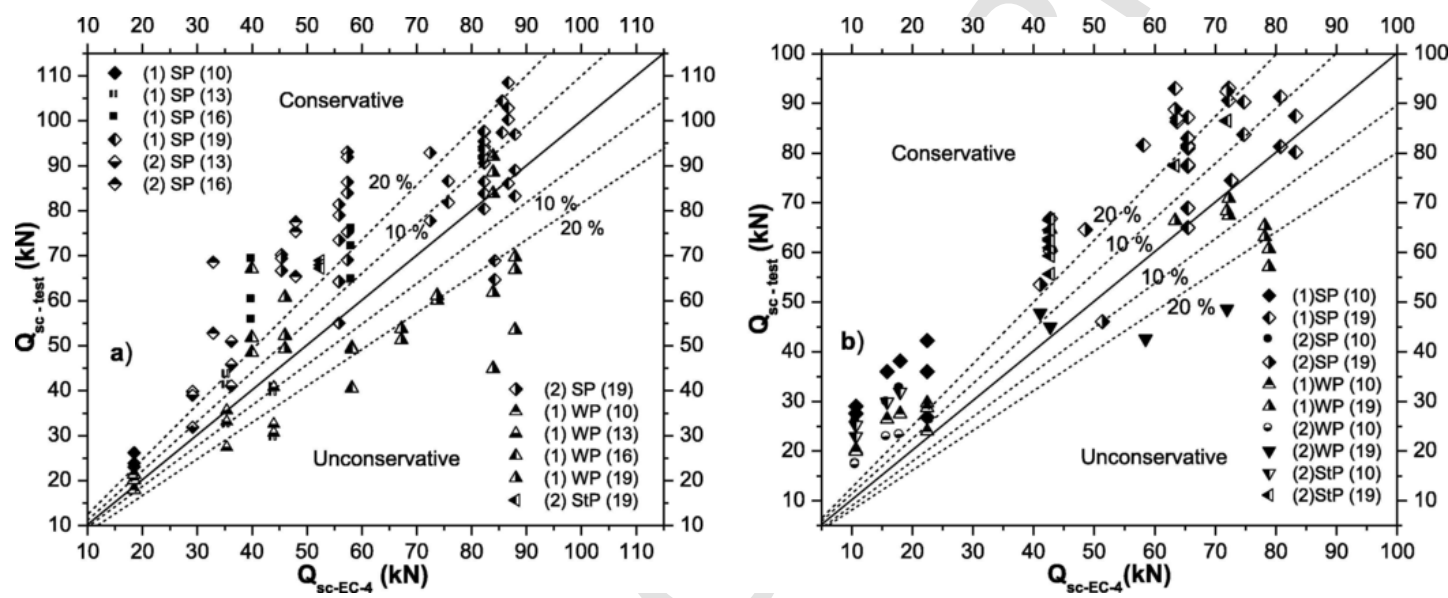

Fig. 16. Prediction of the shear resistance according to Eurocode 4 for profiled steel sheeting with different heights (hr): (a) hr $=51 \mathrm{and} 60 \mathrm{~mm}$, and (b) hr $=76 \mathrm{and} 80 \mathrm{~mm}$.

Table 7

Statistical data from results generated using different procedures.

\begin{tabular}{|c|c|c|c|c|c|c|}
\hline \multirow[b]{2}{*}{$\begin{array}{l}\text { Statistical } \\
\text { parameters }\end{array}$} & \multicolumn{2}{|l|}{$h_{r}=25 \mathrm{~mm}$} & \multicolumn{2}{|c|}{$\begin{array}{l}h_{r}=51 \text { and } \\
60 \mathrm{~mm}\end{array}$} & \multicolumn{2}{|c|}{$\begin{array}{l}h_{r}=76 \text { and } \\
80 \mathrm{~mm}\end{array}$} \\
\hline & $\begin{array}{l}\mathrm{Q}_{\text {sc- }} \\
\text { test } \\
\text { AISC- } \\
\text { Alc- } \\
\text { LRFD }\end{array}$ & $\begin{array}{l}\mathrm{Q}_{\text {sc- }} \\
\text { test } / \mathrm{Q}_{\text {sc- }} \\
\mathrm{EC}-4\end{array}$ & $\begin{array}{l}\mathrm{Q}_{\text {sc- }} \\
\text { test } / \mathrm{Q}_{\text {sc- }} \\
\text { AISC- } \\
\text { LRFD }\end{array}$ & $\begin{array}{l}\mathrm{Q}_{\text {sc- }} \\
\text { test } / \mathrm{Q}_{\text {sc- }} \\
\text { EC-4 }\end{array}$ & $\begin{array}{l}\mathrm{Q}_{\text {sc- }} \\
\text { test } / \mathrm{Q}_{\text {sc- }} \\
\text { AISC- } \\
\text { LRFD }\end{array}$ & $\begin{array}{l}\mathrm{Q}_{\text {sc- }} \\
\text { test } / \mathrm{Q}_{\text {sc- }} \\
\mathrm{EC-}-4\end{array}$ \\
\hline Mean & 0.76 & 0.90 & 0.91 & 1.11 & 0.98 & 1.31 \\
\hline Maximum value & 1.00 & 1.15 & 1.24 & 2.09 & 1.84 & 2.42 \\
\hline Minimum value & 0.53 & 0.69 & 0.58 & 0.54 & 0.56 & 0.64 \\
\hline $\begin{array}{l}\text { Coefficient of } \\
\text { variation }\end{array}$ & 0.26 & 0.19 & 0.17 & 0.24 & 0.26 & 0.30 \\
\hline $\begin{array}{l}\mathrm{Q}_{\text {sc-test }} / \mathrm{Q}_{\text {sc-AISC- }} \\
\text { LRFD } / \text { EC-4 } \\
(\% 0.8 \\
(\%)\end{array}$ & 50.0 & 50.0 & 24.0 & 15.0 & 21.9 & 7.3 \\
\hline $\begin{array}{l}0.8<\mathrm{Q}_{\text {sc- }} \\
\text { test } / \mathrm{Q}_{\text {sc-AISC- }} \\
{ }_{\text {LRFD }} / \text { EC-4 } \\
(\% 1 \\
(\%)\end{array}$ & 41.7 & 8.3 & 50.0 & 18.0 & 43.9 & 12.2 \\
\hline $\begin{array}{l}1<\mathrm{Q}_{\text {sc-test }} / \mathrm{Q}_{\text {sc- }} \\
\text { AISC- } \\
\text { LRFD } / \text { EC-4 }<1.2 \\
(\%)\end{array}$ & 8.3 & 41.7 & 23.0 & 34.0 & 14.6 & 20.7 \\
\hline $\begin{array}{l}\mathrm{Q}_{\text {sc-test }} / \mathrm{Q}_{\text {sc-AISC- }} \\
\text { LRFD } / \text { EC-4 }>1.2 \\
\quad(\%)\end{array}$ & 0.0 & 0.0 & 3.0 & 33.0 & 19.5 & 59.8 \\
\hline
\end{tabular}

\subsection{Application of load}

The load was applied incrementally on the web of the steel profile, as shown in Fig. 7 (a), to small intervals, where the size of such intervals was selected automatically by ABAQUS [24,27], based on the condition of numerical convergence. In this case, the load was applied using the modified RIKS algorithm [24,27]. The basis of this algorithm is the Newton method, in which the solution is obtained as a series of increments with iterations to obtain equilibrium within each increment. The RIKS method is generally used to predict unstable and nonlinear collapse of a structure. It uses the load magnitude as an additional unknown and solves simultaneously for loads and displacements. Therefore another quantity must be used to measure the progress of the solution. ABAQUS $[24,27]$ uses the arc length along the static equilibrium path in load-displacement space. An initial increment of displacement is given on the data line and the initial load proportionality factor is equal to this initial increment using the automatic incremental scheme. This initial increment is adjusted if the increment fails to converge. From then on, the value of load after each increment is computed automatically. The solution ends either by specifying the maximum value of the load or a maximum displacement value at a specified degree of freedom.

The slip of the steel beam relative to the composite slab for each load increment is measured at point 1 (see Fig. 7 (a)). 


\subsection{Boundary conditions}

Stud shear connector: There are two surfaces of interaction: the stud-W steel beam interface, and the stud-concrete interface. The stud-concrete contact is a complex subject and some different approaches can be found. In references [37-39], researchers presented efficient nonlinear models to deal with the interface between steel and concrete. In references [8-10,12] researchers presented a simple approach detaching the nodes behind the stud from the surrounding concrete, in the direction of loading - all other nodes were kept attached. In this research, stud-concrete interface is considered as in [8-10,12] as the basis for the study. Rigid contact in the stud-concrete interface was adopted, detaching nodes along " $\mathrm{h} / 2$ " (see Fig. 7 (b)) that did not participate in stud-concrete contact. This approach showed very good numerical results compared to experimental data as can be seen in [40]. Basic experimental observations suggested that the separation of the concrete behind the shear connector occurred even at low load levels [4]. It is worth commenting that considering this type of contact between stud and concrete surfaces, numerical convergence problems are further prevented.

The option (*TIE CONSTRAINT) in ABAQUS [24] is used to specify a rigid contact. A tie constraint ties two separate surfaces together so that there is no relative motion between them. This type of constraint allows for two regions to be together even though the meshes created on the surfaces of the regions do not match. A surface-based tie constraint can be used to make the translational and rotational motion as well as all other active degrees of freedom equal for a pair of surfaces. From the numerical point of view, in this case, to generate contact, the surface-to-surface formulation is utilized.

Composite slab: The friction force that is generated in the composite slab-W beam section contact is not considered, as is usually done in push-out tests [30]. Only a normal contact between both materials was generated. The support of the slab is obtained in the lower part (surface 1 in Fig. 7 (a)); all nodes of the concrete slab in the opposite direction of loading (surface 1 ) are restricted from moving in the $\mathbf{Z}$ direction to resist the compression load. Based on various researchers' work, the profiled steel sheeting-concrete contact is considered as a rigid surface [10,41].

W steel beam: The W steel beam is connected to stud shear connectors by a rigid surface, already mentioned. The distributed load is applied on the web of the W steel profile, in a similar way to the push-out test.

\section{Verification of the finite element model}

In the previous sections the procedure and considerations to develop the FE model were explained based on the Jayas and Hosain's [4] JDT-8 test specimen. In this section, push-out tests conducted by Jayas and Hosain [4], Robinson [3], Rambo-Roddenberry [2] and Lyons et al. [6] are used to verify the accuracy of the FE model. Table 2 summarizes the measured dimensions and concrete cylinder strengths of the tested specimens. Table 3 shows a comparison of the shear connector resistance obtained experimentally and numerically. It can be seen that good agreement has been achieved between both results for most of the push-out tests. A maximum $\mathrm{Q}_{\text {sc-test }} / \mathrm{Q}_{\mathrm{sc}-\mathrm{FE}}$ ratio of 1.072 between experimental and numerical results was obtained for the push-out test of the JDT-6 specimen. The mean value of the $\mathrm{Q}_{\text {sc-test }} / \mathrm{Q}_{\text {sc-FE }}$ ratio is 1.030 with a corresponding coefficient of variation (COV) of 0.034 , as shown in Table 3.

The experimental load-slip curves obtained for JDT-5 and JDT-6 were compared with the numerical curves obtained from the FE analysis, as shown in Fig. 8. Generally, good agreement has been achieved between experimental and numerical load-slip curves. It can be seen that the FE models successfully predicted the resistance of shear connection and the load-slip behavior of the headed shear stud. For the specimen JDT-5 the maximum load per stud recorded experimentally was $40.87 \mathrm{kN}$ at slip of $2.2 \mathrm{~mm}$ compared with $38.75 \mathrm{kN}$ and $2.3 \mathrm{~mm}$, respectively, obtained from the FE analysis. For the specimen JDT-6, the maximum load recorded experimentally was $57.56 \mathrm{kN}$ at slip of $3.4 \mathrm{~mm}$ compared with $53.68 \mathrm{kN}$ and $3.2 \mathrm{~mm}$, obtained from the FE analysis. Therefore, the FE model is capable of predicting experimental results in an accurate way.

\subsection{Stress contours and deformed shapes for test specimen JDT-8}

The failure mode observed experimentally for specimen JDT- 8 of Jayas and Hosain [4] was compared with that predicted numerically. The failure mode was concrete conical failure as observed experimentally and confirmed numerically. Fig. 9 shows the stress contour (in Pa) at failure of specimen JDT- 8 obtained using the FE model. It should be noted that the maximum stresses in the concrete are in the regions around the stud, forming a conical shape. This conical failure mode of concrete has been explained in detail both experimentally and numerically by Ellobody and Young [10], and Lam and Ellobody [12] in their investigation of push-out tests with solid slabs and composite slabs using profiled steel sheeting. The conical concrete failure is also known as concrete pullout failure since the tensile force acting on the stud forces the slab to move up and leave a cone of concrete around the stud.

Concrete conical failure (or concrete pull-out) was also observed experimentally and discussed theoretically in previous studies on push-out tests with profiled steel sheeting conducted by Hawkins and Mitchell [42], and Lloyd and Wright [43]. Concrete conical failure occurred as well when the stud reached its yield stress near the collar. Fig. 10 shows the deformed shape and stress contours (in Pa) of the $19 \times 127 \mathrm{~mm}$ headed stud shear connector for the specimen JDT-8, obtained from the FE analysis.

\section{Study of different factors influencing the resistance of the stud shear connector}

In this section the effect of stud position inside the rib of profiled steel sheeting and the effect of concrete strength on stud shear resistance are investigated.

Several researchers have shown that the position of the stud in the deck has significant impact on the stud shear resistance $[2,5-7,43]$.

\subsection{Effect of stud position on the stud shear resistance}

Most profiled steel sheeting has a central stiffener in the middle of the deck rib and studs welded off-center of the deck rib may be in strong or weak positions. According to Rambo-Roddenberry [2], the studs can be in a strong position (SP) when $e_{\text {mid-ht }} \geq 56 \mathrm{~mm}$ ( $2.2 \mathrm{in}$ ), and in a weak position (WP) when $e_{\text {mid-ht }}<56 \mathrm{~mm}$. Note that $e_{\text {mid-ht }}$ is defined as the distance from the center of the stud's longitudinal axis to the deck rib, at the mid-height of the rib, on the load bearing side of the stud (as shown in Fig. 11).

In this research, the numerical modeling of push-out test was used to investigate the effect of stud position on shear resistance of stud. The test specimen S6-D53 of Lyons et al. [6] was modeled changing the stud position inside the rib of profiled steel sheeting. The stud connector was placed inside the rib in five different positions with $e_{\text {mid-ht }}$ taking the values of 38, 48, 54, 100 and $130 \mathrm{~mm}$, respectively.

The results from numerical modeling are plotted in Fig. 12 and show that for $e_{\text {mid-ht }}$ values below $60 \mathrm{~mm}$, the stud shear resistance decreases very rapidly. This value is very similar to the value of $56 \mathrm{~mm}$ established by Rambo-Roddenberry [2]. In fact, based on this numeri- 
cal study and taking into consideration the experimental studies carried out by Rambo-Roddenberry [2] and also supported by experimental investigations [3,5,7], the influence of the stud position on its shear resistance has been widely confirmed. On the other hand, all the tests performed by Sublett et al. [5], Lyons et al. [6] and Rambo-Roddenberry [2] on strong position studs with strengths of about $0.68 A_{s c} F_{u}$ had an $e_{\text {mid-ht }}$ value of approximately $114 \mathrm{~mm}$. All the tests performed by those authors on weak position studs with strengths of about $0.48 A_{s c} F_{u}$ had an $e_{\text {mid-ht }}$ value of approximately $38 \mathrm{~mm}$.

Sublett et al. [5] and Diaz et al. [28] analyzed the behavior of studs located at the middle position (MP). Values of $e_{\text {mid-ht }}$ close to $23 \mathrm{~mm}$ were obtained for $25 \mathrm{~mm}$ steel deck height while $e_{\text {mid-ht }}$ values close to $27 \mathrm{~mm}$ were obtained for $38 \mathrm{~mm}$ steel deck height. The middle position studs had strengths of about $0.48 A_{s c} F_{u}$, which is the same as the strengths of the weak position studs.

\subsection{Effect of concrete strength on stud shear resistance}

The effect of concrete strength on the strength of studs in solid slabs is well documented [1]. Oehlers and Johnson [44] concluded that increasing the strength of concrete makes studs resist more shear load.

In this case, the stud-concrete interface pressure is distributed across a larger area before stud fracture. Moreover, the flexural forces on the stud are reduced when concrete strength and elastic modulus are increased, thereby, allowing a greater shear load before fracture of the stud.

In this research, the numerical modeling of push-out test was used to investigate the effect of concrete strength on shear resistance of stud connector welded through deck. Initially, the test specimens TI of Robinson [3] and JDT-8 of Jayas and Hosain [4] using stud connectors of 10 and $19 \mathrm{~mm}$ of diameter respectively were modeled, changing the concrete strength from 20 to $40 \mathrm{MPa}$. In both specimens only a single stud in SP was placed. The effect on the stud resistance due to concrete strength changing is graphically shown in Fig. 13. It can be seen that the resistance of the shear connection is significantly increased with the increase of concrete strength.

Experimental and numerical results from push-out test that have identical parameters, except for concrete strength, are compared in Tables 4 and 5. Table 4 shows the effect of concrete strength on the stud shear resistance when studs are placed in the strong and staggered positions, respectively. In Table 4 and Fig. 13, numerical and experimental results (for connectors with $d=13,16$ and $19 \mathrm{~mm}$ in SP and profiled sheeting of $51 \mathrm{~mm}$ in height $\left(\mathrm{h}_{\mathrm{r}}\right)$ ) demonstrate the influence of concrete in increasing stud shear resistance in the range of $14.8 \%$ to $28.01 \%$. The same behavior is observed for profiled steel sheeting of $76 \mathrm{~mm}$ in height $\left(\mathrm{h}_{\mathrm{r}}\right)$ with stud shear resistance increasing in the range of $17.57 \%$ to $53.27 \%$. At the end of Table 4, the same trend can be observed for connectors in StP. It can be seen that the resistance of the shear connection is increased with the increase of concrete strength. Moreover, Table 5 shows the effects of concrete strength on stud shear resistance when studs are placed in the weak position. Notice that the resistance of the shear connection is not significantly increased with the increase of concrete strength. From these observations, it became evident that this parameter significantly influences the shear resistance of the stud connections - especially when the connectors are placed in SP or StP positions.

\section{Comparison of FE and push-out test results with the design shear resistance}

The shear connection resistances obtained from the FE analysis and the push-out test results available in the literature were compared with the nominal unfactored design strengths of headed stud shear connec- tors predicted by the AISC-LRFD [29] and Eurocode 4 [30]. The AISC-LRFD equation for the calculation of the design strength of headed stud shear connector $\left(\mathrm{Q}_{\mathrm{sc}-\mathrm{AISC}-\mathrm{LRFD}}\right)$ in composite beams with profiled steel sheeting with ribs perpendicular to the steel beam is given as:

$Q_{s c-A I S C-L R F D}=0.5 \cdot A_{s c} \cdot \sqrt{f_{c}^{\prime} \cdot E_{c}} \leq R_{g} \cdot R_{p} \cdot A_{s c} \cdot F_{u}$

In the AISC-LRFD [29], in order to design the concrete-steel composite section (with concrete slab using profiled steel sheeting with ribs oriented perpendicular to the longitudinal axis of the steel beam) the correct use of the inequality in expression (7) is required. When the right member of the inequality is used, the compressive strength of the concrete $\left(f_{c^{\prime}}\right)$ is not taken into account (see expression (7)). However, the compressive strength of concrete is a significant parameter, especially when stud connectors are placed inside the steel deck ribs in the so called strong position and also in the staggered position (see Fig. 11).

As can be observed, expression (7) with the Rp coefficient takes into account the shear connector position inside the rib of profiled steel sheeting. Such a position influences the shear resistance of the stud connectors.

European Code (EC-4) [30] defines expression (8) for calculating the shear resistance for headed stud connectors in the composite section made up of solid concrete slabs.

$Q_{s c-E C-4}=0.29 \cdot \alpha \cdot d^{2} \cdot \sqrt{f_{c k} \cdot E_{c m}} \leq 0.8 \cdot A_{s c} \cdot f_{u}$

In expression (8) the value of $\alpha$ is determined from the following expression (9):

$\alpha=0.2\left(\frac{h}{d}+1\right)$ for $3 \leq \frac{h}{d} \leq 4$, and $\alpha=1$ for $\frac{h}{d}>4$

For composite section made of concrete slab and steel deck ribs orientated perpendicular to the I-beam axis, it is necessary to reduce the value obtained in expression ( 8 ) by multiplying this value by the coefficient $(k t)$ derived from the following expression (10).

$k_{t}=\frac{0.7}{\sqrt{n_{r}}} \cdot \frac{w_{r}}{h_{r}} \cdot\left(\frac{h}{h_{r}}-1\right)$

Notice that in expression (8) the shear connector position inside the rib of profiled steel sheeting is not taken into account. However, based on the analyses in Section 4, the stud position greatly influences the shear resistance of stud connectors. Consequently, one important parameter that might be considered in the expression for evaluating the shear resistance is the stud position inside the rib.

The design shear resistances calculated using AISC-LRFD [29] and Eurocode 4 [30] were verified against results obtained from the FE analysis and the test results carried out by various researchers such as Diaz et al. [28], Rambo-Roddenberry [2], Lyons et al. [6], Sublett et al. [5], Johnson and Yuan [7], Jayas and Hosain [4] and Robinson [3]. Some test parameters from these experimental studies are shown in Table 6.

In Figs. 14-16, the symbol (X)Y(Z) means $\mathrm{X}=$ number of studs, $\mathrm{Y}=$ stud position, $\mathrm{Z}=$ stud diameter. In such figures, the trend (conservative, unconservative), in the shear resistance value can be noticed considering the two methods studied in this section. In Figs. 14 and 15, it is interesting to see how the AISC-LRFD [29] procedure showed a clear trend to overestimate the stud shear resistance. Prediction according to Eurocode 4 [30] shows slight scattering of results when compared to the other method analyzed (AISC-LRFD). 
In Fig. 16 (a), for $h_{r}=51 \mathrm{~mm}$ and $60 \mathrm{~mm}$, it can be seen that EC-4 gives conservative results greater than $20 \%$ - mainly for SP and StP. It can also be observed, in the same figure, that for WP, EC-4 gives unconservative results greater than $20 \%$. In Fig. 16 (b), for $h_{r}=76 \mathrm{~mm}$ and $80 \mathrm{~mm}$; there is a visible overall trend to to give conservative values greater than $20 \%$ for SP and, to a lesser extent, unconservative results for WP.

Table 7 shows the statistical data where the nominal unfactored design shear resistance of headed stud shear connectors $\left(Q_{s c-A I S C-L R F D}\right.$ and $\mathrm{Q}_{\text {sc - EC-4 }}$ ) is compared with data from experimental tests and FE analysis. The mean values of $\mathrm{Q}_{\text {sc-test }} / \mathrm{Q}_{\text {sc-AISC-LRFD }}$ and $\mathrm{Q}_{\text {sc-test }} / \mathrm{Q}_{\text {sc-EC-4 }}$ ratios, in steel deck with heights of 25,51 and 60 , and 76 and $80 \mathrm{~mm}$ are 0.76 , $0.90,0.91,1.11,0.98$ and 1.31 , respectively, with the corresponding coefficients of variation (COV) of $0.26,0.19,0.17,0.24,0.26$ and 0.30 , respectively. The AISC-LRFD [29] predictions were generally more unconservative than the Eurocode 4 [30] predictions, except for some cases that underestimated the shear resistance of the connection, as can be seen at the end of Table 7. Eurocode 4 [30] shows a trend towards nonconservative values especially for connectors in WP and excessively conservative values in other cases (SP, StP).

\section{Conclusions}

Accurate nonlinear FE models have been developed to investigate the behavior of shear connection in composite beams with profiled steel sheeting with ribs perpendicular to the steel beam. The results obtained from FE analyses were verified against experimental results. The FE models successfully predicted the resistance of shear connection and the load-slip behavior of the headed shear stud. Parametric studies were conducted to investigate the effects on the resistance and behavior of shear connection by changing the stud position inside the rib of profiled steel sheeting and the concrete strength. One conclusion of this research is that concrete properties have a great influence on the shear resistance of stud connectors, mainly when the studs are in strong position (SP) or in staggered position (StP). It is noted that in strong position $e_{\text {mid-ht }} \geq 56 \mathrm{~mm}$ (2.2 in) and in weak position, $e_{\text {mid-ht }}<56 \mathrm{~mm}$, where $e_{\text {mid-ht }}$ is the distance from the center of the stud's longitudinal axis to the deck rib. Experimental and numerical results lead to the conclusion that the stud position is an important parameter to be taken into account for the calculation of the shear resistances of stud connectors. The design shear resistances calculated using AISC-LRFD and Eurocode 4 were verified against results obtained from the $\mathrm{FE}$ analyses and the test results carried out by various researchers. The results of this research indicate: (1) AISC-LRFD procedure has a clear trend to overestimate the stud shear resistance; and (2) the design rules specified in Eurocode 4 were, generally, very conservative, except for some cases when the resistance of shear connection is excessively overestimated, mainly when the studs are in weak positions (WP).

\section{Acknowledgements}

Authors are very thankful to CAPES (Brazilian Coordination for the Improvement of Higher Education Personnel) for the financial support for this research.

\section{References}

[1] J.G. Ollgaard, R.G. Slutter, J.W. Fisher, Shear strength of stud connectors in lightweight and normal-weight concrete, Eng J AISC 8 (1971) 55-64.

[2] Rambo-Roddenberry MD. Behavior and strength of welded stud shear connectors. University of Blacksburg, Virginia, EE.UU; 2002.

[3] H. Robinson, Multiple stud shear connectors in deep ribbed metal deck, Can J Civ Eng 15 (1988) 553-569.

[4] B.S. Jayas, M.U. Hosain, Behavior of headed studs in composite beams: push-out test, Can J Civ Eng 15 (1988) 240-253.
[5] Sublett CN, Easterling WS, Murray TM. Strength of welded headed studs in ribbed metal deck on composite joist. Report No. CE/VPI-ST 92/03; 1992.

[6] Lyons JC, Easterling WS, Murray TM. Strength of welded shear studs. Report No. CE/VPI-ST 94/07. Blacksburg, VA; 1994.

[7] Johnson RP, Yuan H. Resistance of stud shear connectors in troughs of profiled sheeting. Research report CE 55. Warwick, UK; 1997.

[8] J. Bonilla, L.M. Bezerra, R. Larrúa, C. Recarey, E. Mirambell, Modelación numérica con validación experimental aplicada al estudio del comportamiento de conectores tipo perno de estructuras compuestas de hormigón y acero, Revista Ingeniería de Construcción 30 (2015) 53-68, https://doi.org/10.4067/S071850732015000100005

[9] J. Bonilla, E. Mirambell, R. Larrúa, C. Recarey, Behavior and strength of welded stud shear connectors in composite beam, Rev Fac Ing Univ Antioquia (2012) 93-104.

[10] E. Ellobody, B. Young, Performance of shear connection in composite beams with profiled steel sheeting, J Constr Steel Res (2006) 682-694.

[11] H. Hernández, J. Bonilla, G. Rodríguez, Estudio del comportamiento de vigas compuestas de hormigón y acero mediante simulación numérica, Revista Ingeniería de Construcción 29 (2014) 5-21, https://doi.org/10.4067/S071850732014000100001

[12] D. Lam, E. Ellobody, Behavior of headed stud shear connectors in composite beam, J Struct Eng 131 (2005) 96-106.

[13] K. Alenezi, M.M. Tahir, T. Alhajri, M.R.K. Badr, J. Mirza, Behavior of shear connectors in composite column of cold-formed steel with lipped C-channel assembled with ferro-cement jacket, Constr Build Mater 84 (2015) 39-45, https://doi.org/10. 1016/j.conbuildmat.2015.03.015.

[14] P. Lu, X. Xie, C. Shao, Experimental study and numerical analysis of a composite bridge structure, Constr Build Mater 30 (2012) 695-705, https://doi.org/10.1016/ j.conbuildmat.2011.11.008.

[15] X. Xu, Y. Liu, J. He, Study on mechanical behavior of rubber-sleeved studs for steel and concrete composite structures, Constr Build Mater 53 (2014) 533-546, https: //doi.org/10.1016/j.conbuildmat.2013.12.011.

[16] C. Rethnasamy, T. Rajagopal, H. Muthuraj, Bending behavior, deformability and strength analysis of Prefabricated Cage Reinforced Composite beams, Constr Build Mater 38 (2013) 482-490, https://doi.org/10.1016/j.conbuildmat.2012.08.017.

[17] H. Ban, M.A. Bradford, B. Uy, X. Liu, Available rotation capacity of composite beams with high-strength materials under sagging moment, J Constr Steel Res (2016) 156-168, https://doi.org/10.1016/j.jcsr.2015.11.008

[18] M. Pavlović, Z. Marković, M. Veljković, D. Buđevac, Bolted shear connectors vs headed studs behaviour in push-out tests, J Constr Steel Res (2013) 134-149, https://doi.org/10.1016/j.jcsr.2013.05.003.

[19] H.T. Nguyen, S.E. Kim, Finite element modeling of push-out tests for large stud shear connectors, J Constr Steel Res (2009) https://doi.org/10.1016/j.jcsr.2009. 06.010, 1909_1920.

[20] F. Tahmasebinia, G. Ranzi, A. Zona, Probabilistic three-dimensional finite element study on composite beams with steel trapezoidal decking, J Constr Steel Res (2013) 394-411, https://doi.org/10.1016/j.jcsr.2012.10.003.

[21] J. Qureshi, D. Lam, Behaviour of headed shear stud in composite beams with profiled metal decking, Adv Struct Eng 15 (2012) 1547-1558, https://doi.org/10. 1260/1369-4332.15.9.1547.

[22] J. Qureshi, D. Lam, J. Ye, The influence of profiled sheeting thickness and shear connector's position on strength and ductility of headed shear connector, Eng Struct 33 (2011) 1643-1656, https://doi.org/10.1016/j.engstruct.2011.01.035.

[23] I.E.J. Henderson, X.Q. Zhu, B. Uy, O. Mirza, Dynamic behaviour of steel-concrete composite beams retrofitted with various bolted shear connectors, Eng Struct 131 (2017) 115-135, https://doi.org/10.1016/j.engstruct.2016.10.021.

[24] ABAQUS. User's manuals. Version 6.14-1. Hibbitt Karlsson and Sorensen, Inc., USA; 2014.

[25] J. Lubliner, J. Oliver, S. Oller, E. Oñate, A plastic-damage model for concrete, Int J Solids Struct 25 (1989) 229-326.

[26] J. Lee, G.L. Fenves, Plactic-damage model for cyclic loading of concrete structures, J Eng Mech 124 (1998) 892-900.

[27] ABAQUS. Theory manual. Version 6.14-1. Hibbitt Karlsson and Sorensen, Inc., USA; 2014.

[28] Diaz B, Easterling WS, Murray TM. Behavior of welded shear studs used with $1.0 \mathrm{C}$ Deck. Internal report, Blacksburg, VA; 1998.

[29] Load and Resistance Factor Design (LRFD) Specification for Structural Steel Building (2010). American Institute of Steel Construction (AISC), Inc.; 2010.

[30] EN 1994-1-1: 2004 Design of Composite Steel and Concrete Structures Part 1.1 (2004). European Committee for Standardization; 2004.

[31] ABAQUS. Example problems manual. Version 6.14-1, Hibbitt Karlsson and Sorensen, Inc., USA; 2014.

[32] S. Oller, J. Oliver, J. Lubliner, E. Oñate, Un Modelo Constitutivo de Daño Plástico para Materiales Friccionales. Parte - 1: Variables Fundamentales, Funciones de Fluencia y Potencial, Revista Internacional de Métodos Numéricos Para Cálculo Y Diseño En Ingeniería 4 (1988) 397-431.

[33] EN1992-1-1: Eurocode 2 - Design of concrete structures. Part 1-1: General rules and rules for buildings. Brussels, Belgium: European Committee for Standardization (CEN); 2004.

[34] W. Krätzig, R. Pölling, An elasto-plastic damage model for reinforced concrete with minimum number of material parameters, Comput Struct (2004) 1201-1215, https://doi.org/10.1016/j.compstruc.2004.03.002. 
[35] Birtel V, Mark P. Parameterised finite element modelling of RC beam shear failure. In: The 19th annual international ABAQUS users' conference, Boston, USA; 2006. p. 95-108.

[36] J. Bonilla, Estudio del comportamiento de conectores tipo perno de estructuras compuestas de hormigón y acero mediante modelación numérica, Central University of Las Villas, 2008.

[37] E. Brunesi, R. Nascimbene, M. Deyanova, C. Pagani, S. Zambelli, Numerical simulation of hollow steel profiles for lightweight concrete sandwich panels, Comput Concr 15 (2015) 951-972.

[38] E. Brunesi, R. Nascimbene, G.A. Rassati, Response of partially-restrained bolted beam-to-column connections under cyclic loads, J Constr Steel Res (2014) 24-38, https://doi.org/10.1016/j.jcsr.2014.01.014.

[39] E. Brunesi, R. Nascimbene, G.A. Rassati, Seismic response of MRFs with partially-restrained bolted beam-to-column connections through FE analyses, J Constr Steel Res (2015) 37-49, https://doi.org/10.1016/j.jcsr.2014.12.022.
[40] J. Bonilla, R. Larrúa, E. Mirambell, C. Recarey, Estudio de la influencia de la resistencia del hormigón en el comportamiento de conectadores mediante simulación numérica y análisis experimental, Ingeniería Civil (2007) 57-64.

[41] J. Bonilla, R. Larrúa, C. Recarey, E. Mirambell, A. Gómez, M. López, Simulación numérica del ensayo push-out para conectores tipo perno de estructuras mixtas en sección viga-losa con lámina nervada, Ingeniería Civil (2010) 109-120.

[42] N.M. Hawkins, D. Mitchell, Seismic response of composite shear connections, J Struct Eng 110 (1984) 2120-2136.

[43] R.M. Lloyd, H.D. Wright, Shear connection between composite slabs and steel beams, J Constr Steel Res 15 (1990) 255-285.

[44] D.J. Oehlers, R.P. Johnson, The strength of stud shear connections in composite beams, Struct Engineer 65 (1987) 44-48. 